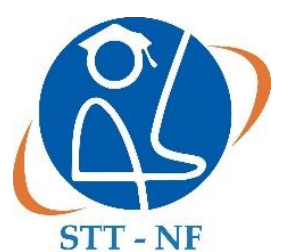

STT - NF $\underline{\text { Jurnal Teknologi Terpadu }}$

Journal of Integrated Technology

https://journal.nurulfikri.ac.id/index.php/JTT

ISSN : 2477-0043 ISSN ONLINE : 2460-7908

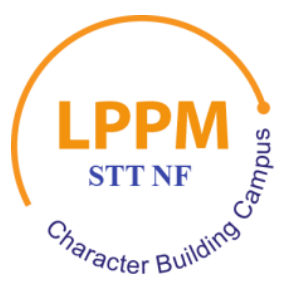

\title{
MELIHAT PETA PENYEBARAN PASIEN COVID-19 DENGAN KOMBINASI QGIS DAN FRAMEWORK LARAVEL
}

\author{
Muhammad Ullil Fahri \\ Manajemen Informatika, Akademi Manajemen Komputer dan Informatika (AMKI) Ketapang \\ Ketapang, Kalimantan Barat, Indonesia \\ muhammad.fahri001@binus.ac.id
}

\begin{abstract}
The local government of Ketapang Regency has difficulty tracking the distribution of covid-19 patients. This difficulty is attributed to the data used in the form of tables and coordinate points. In this study, the authors transformed data tables that are difficult to understand into mapping visualization data so that they can easily see which areas have the most ODP, PDP and Positive. With the increasing epidemic of Covid-19 in Indonesia, local governments must be able to make decisions quickly. One way to be able to support the local government in making decisions on Covid19 by making a distribution of Covid-19 patients based on coordinate maps that can be accessed by parties who have interests in real time via the website. The method used in this research is digitalisis mapping using 2 applications, QGIS and framework laravel. The results of making the mapping application of Covid-19 patients are very accurate in providing a visual picture of the distribution of Covid-19 patients in an area..
\end{abstract}

Keywords: Covid-19, QGIS, framework Laravel

\begin{abstract}
Abstrak
Pemerintah daerah Kabupaten Ketapang kesulitan dalam melacak sebaran pasien Covid-19. Kesulitan ini dikarenakan data yang digunakan masih dalam bentuk tabel dan titik koordinat. Pada Penelitian ini penulis melakukan transformasi dari data tabel yang sulit dipahami menjadi data visualisasi mapping sehingga dapat dengan mudah melihat daerah mana saja yang paling banyak terdapat kasus ODP, PDP, dan Positif. Dengan meningkatnya wabah Covid-19 di Indonesia membuat pemerintah daerah harus bisa mengambil keputusan dengan cepat. Salah satu cara agar dapat mendukung pemerintah daerah dalam mengambil keputusan terhadap Covid-19 dengan membuat sebaran pasien Covid-19 berdasarkan peta koordinat yang dapat diakses oleh pihak yang memiliki kepentingan secara real time melalui website. Metode yang dilakukan dalam penelitian ini adalah pemetaan digitalisasi dengan menggunakan dua aplikasi yaitu QGIS dan framework Laravel. Hasil pembuatan aplikasi pemetaan pasien Covid-19 ini sangat akurat dalam memberikan gambaran visual sebaran pasien Covid-19 pada suatu daerah.
\end{abstract}

Kata kunci: Covid-19, QGIS, Framework Laravel

\section{PENDAHULUAN}

Pada saat ini sedang terjadi pandemi yang sangat luar biasa di Indonesia. Khususnya di Kabupaten Ketapang, Pemerintah daerah kesulitan dalam melihat peta sebaran pasien Covid-19. Kesulitan dalam melihat sebaran adalah masih menggunakan data tabel yang berisi nama dan titik koordinat dari rumah pasien ODP (Orang
Dalam Pantauan), PDP (Pasien Dalam Pemantauan), dan Positif Covid-19. Hal ini terasa sangat mengganggu ketika pihak BNPB Ketapang diminta memberikan pertanggung jawaban oleh pihak yang berkepentingan. Misalnya ketika diminta daerah mana saja yang terdapat pasien ODP Terbanyak. Dengan adanya aplikasi pemetaan digitalisasi dipastikan dapat membantu pihak 
- pihak yang berkepentingan ingin mendapatkan informasi secara real time tentang kondisi daerah berdasarkan titik koordinat. Pandemi Virus Covid-19 ini menyebar sangat cepat dari manusia ke manusia. Dengan adanya peta penyebaran, maka dapat membantu manusia melihat secara visualisasi penyebaran terjadi di mana saja. Dalam hal ini penyebaran berdasarkan koordinat pasien ODP, PDP, OTG (Orang Tanpa Gejala), Rapid Tes Reaktif, dan Positif Covid-19. Dengan didapatkannya peta penyebaran yang dapat diakses oleh pihak yang memiliki kepentingan, maka dapat membantu proses analisa pemerintah dalam mengambil kebijakan. Pada saat ini penyebaran Covid19 sangat cepat di beberapa negara.

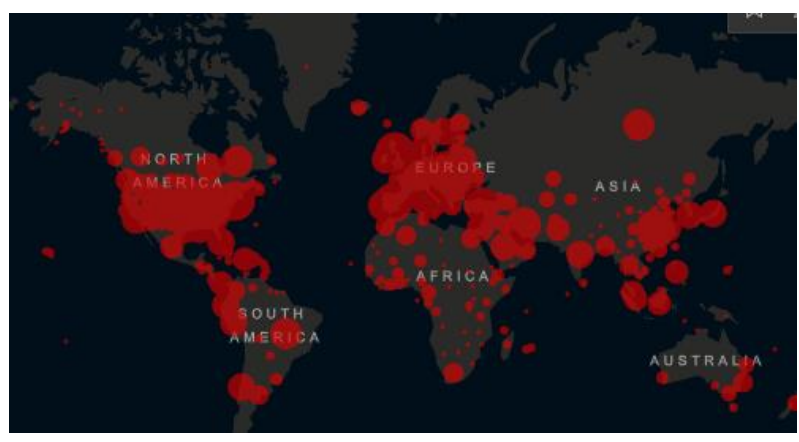

Gambar 1. Sebaran Covid-19 Di dunia [1]

Pada Gambar 1 merupakan sebaran Covid-19 di dunia [1]. Dari peta pada Gambar 1 dapat dilihat penyebaran Covid-19 sangat cepat. Pada data tanggal 18 April 2020, total kasus Covid-19 di dunia telah mencapai angka lebih dari 2 jutaan. Sedangkan total kasus Covid-19 di Indonesia pada tanggal 18 April 2020 telah mencapai angka 6 ribuan. Dengan sebaran peta seperti pada Gambar 2.

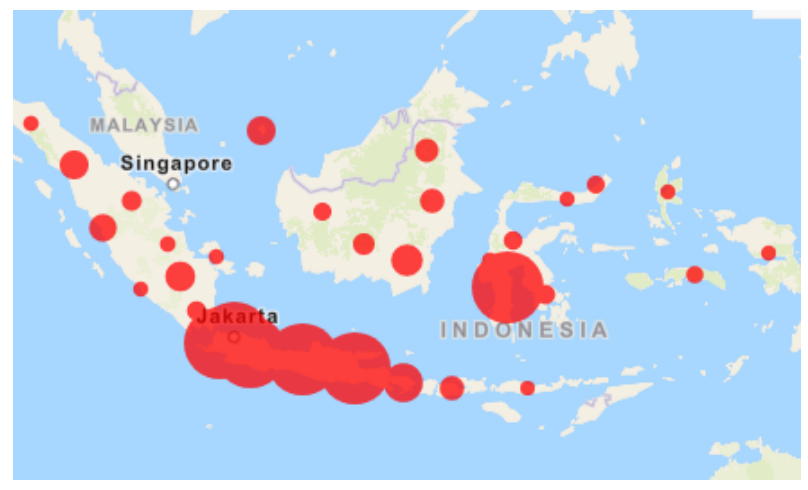

Gambar 2. Sebaran Covid-19 Di dunia [2]

Pada gambar 2 merupakan peta sebaran kasus Covid-19 di Indonesia [2]. Dari peta tersebut dapat dilihat semakin besar kolom merah maka semakin banyak kasus positif Covid-19. Menurut [3], Proses pelaporan manual menjadi tidak berkelanjutan ketika wabah berkembang dna peneliti mengadopsi strategi aliran data hidup semiotomatis. Dari pendapat peneliti tersebut dapat dilihat pendataan secara manual tidak dapat dilakukan lagi ketika wabah Covid-19 berkembang dengan sangat cepat. Pendataan manual yang dimaksud adalah pendataan yang dimulai dari kertas kemudian dilaporkan ke suatu unit yang membuat penumpukan laporan. Peneliti berinisiatif membuat laporan menggunakan web-based sehingga laporan lebih cepat. Sering kali masyarakat di beberapa kecamatan kesulitan menemukan fasilitas pelayanan publik yang terdekat [1]. Fasilitas pelayanan publik yang digunakan oleh masyarakat, diantaranya seperti ATM, SPBU, Puskesmas, Rumah Sakit, PAUD, dan Bengkel. Solusi yang dapat dilakukan untuk permasalahan tersebut salah satunya adalah memanfaatkan aplikasi Quantum GIS (QGIS) untuk pemetaan fasilitas layanan masyarakat. Dari pendapat ahli dapat diambil kesimpulan aplikasi QGIS mampu membuat titik - titik lokasi untuk pemetaan. Dalam Penelitian ini menggunakan aplikasi QGIS untuk membuat titik sebaran Pasien Covid-19. Sebaran tersebut terdiri dari ODP, PDP, OTG, Reaktif, dan Positif. Dengan adanya sebaran pasien Covid-19 maka dapat membantu dengan cepat membantu pemerintah membaca sebuah peluang untuk merumuskan sesuatu pada suatu wilayah. Framework Laravel dengan PHP programming language akan mendukung Geographic Information System (GIS) dengan baik [4]. Sangat jelas framework laravel yang menggunakan bahasa pemrograman PHP mendukung sistem dari GIS. Dengan menggunakan aplikasi berbasiskan web yang menggunakan kerangka Laravel maka pengguna tidak perlu membuka aplikasi QGIS. Dalam pembaruan data cukup menggunakan versi dari web-based maka secara otomatis data diperbarui sesuai data titik di peta berdasarkan koordinat dari pasien Covid-19.

Dengan dibuatnya pemetaan secara otomatis yang dibuat dengan QGIS ditambah dengan kombinasi framework Laravel maka kedepannya source code dari hasil aplikasi ini akan dijadikan open source. Dengan dijadikannya open source maka aplikasi pemetaan untuk Covid dapat digunakan secara bebas dengan data berdasarkan wilayah masing - masing. Dalam Penelitian ini, peneliti menggunakan metode pemetaan digitalisasi. Dari hasil digitalisasi tersebut dijadikanlah sebuah web. Dengan adanya web tersebut maka pengguna tidak perlu kesusahan lagi ketika diminta memperbarui titik lokasi pasien. Pengguna hanya menambahkan titik pada halaman dashboard admin pasien berdasarkan koordinat $\mathrm{x}$ dan $\mathrm{y}$. Setelah ditambahkan data tersebut maka secara otomatis titik lokasi pasien secara otomatis masuk ke dalam peta digitalisasi QGIS. Dengan tersedianya sistem pemetaan digitalisasi Pasien Covid-19 diharapkan dapat 
membantu melihat penyebaran Covid-19 berdasarkan Desa.

\section{TINJAUAN PUSTAKA}

Pada bagian ini akan dijelaskan mengenai digitalisasi pemetaan, Covid-19, QGIS, dan framework Laravel.

\subsection{Digitalisasi Pemetaan}

Teknologi Sistem Informasi Geografis (SIG) adalah teknologi yang memiliki kemampuan untuk secara geografis mengumpulkan, mengelola, memanipulasi dan memvisualisasikan data spasial (spasial) yang terkait dengan posisi permukaan bumi pada peta sesuai dengan posisi sebenarnya dari permukaan bumi dengan Titik koordinat Informasi [5] dan dapat menghasilkan informasi geografi berupa peta digital [6]. Dari pendapat ahli, dapat disimpulkan pemetaan dengan digitalisasi sangat penting karena dapat melihat atau menerjemahkan data ke bentuk visualisasi pemetaan.

\subsection{Covid-19}

Covid-19 merupakan penyakit menular yang berpotensi menimbulkan kedaruratan kesehatan masyarakat [7] [6]. Saat ini bukan hanya kondisi di negara Indonesia saja yang mengkhawatirkan dan mencekam, tetapi juga bagi seluruh negara belahan dunia lainnya [8]. Hal ini disebabkan karena dampak pandemi Covid-19 ini tidak hanya berakibat pada stabilitas sektor ekonomi dan sosial saja, tetapi juga berdampak pada seluruh sektor. Menurut. Wabah Pandemi Covid-19 memang harus ditanggulangi, dihadapi, dan disikapi dengan penuh kewaspadaan, baik dari penguasa kekuasaan maupun dari warga masyarakat [9]. Dari pendapat ahli dapat dilihat Covid-19 ini sudah banyak merubah cara masyarakat berpikir dan bertindak. Oleh karena itu diharapkan dengan adanya pemetaan pasien Covid-19 ini masyarakat lebih selektif dalam mengambil keputusan jika ingin pergi ke suatu daerah.

\subsection{QGIS}

Divisualkan dalam bentuk WebGIS untuk memudahkan dalam menampilkan informasi spasial [10]. Proses dengan aplikasi QGIS sampai bisa Online [11]. QGIS menjadi salah satu studi area pada Penelitian ini dan merupakan perangkat lunak pengolah SIG yang bersifat Open Source yang user friendly [12]. Dari pendapat ahli dapat disimpulkan QGIS dapat dimanfaatkan dengan sangat baik dalam pengolah digitalisasi pemetaan secara online.karena sifatnya yang open source.

\subsection{Framework Laravel}

Menurut [12], Laravel adalah salah satu web application framework yang bersifat open source. Untuk membangun sebuah website dibutuhkan sebuah framework, yang dapat membantu pembangunan dan pengembangan website itu sendiri sehingga developer tidak perlu membangun sebuah website dari awal lagi. Salah satu framework yang masih tergolong baru dalam pembuatan sistem informasi berbasis web adalah Laravel [13]. Dari pendapat ahli dapat disimpulkan framework laravel merupakan kerangka sebuah website. Pada penelitian ini akan dikombinasikan antara QGIS dan framework Laravel.

\section{METODE PENELITIAN}

Pada bagian ini berisi penjelasan mengenai tahapantahapan penelitian.

\subsection{Kerangka Pikir}

Kerangka pikir yang digunakan pada penelitian dapat dilihat pada Gambar 3. Kerangka pikir dibangun oleh peneliti agar dapat menyelesaikan sebuah program terapan yang dapat membantu pemerintah daerah.

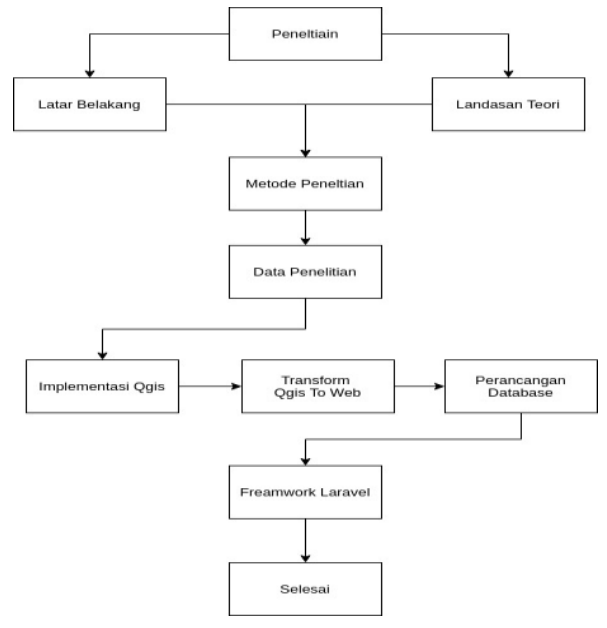

Gambar 3. Kerangka Pikir Penelitian

\subsection{Data penelitian}

Data Penelitian yang digunakan dalam Penelitian adalah data sebaran Covid Kabupaten Ketapang. Dimana didalam data tersebut terdapat beberapa atribut yang dapat digunakan sebagai bahan sampling.

\subsection{Implementasi QGIS}

Data - data yang telah didapatkan mulai di implementasi menggunakan aplikasi QGIS 3. Buatkanlah titik titik koordinat pasien Covid-19 yang termasuk dalam kategori ODP, PDP, Rapid Tes Reaktif, PDP, dan Positif.

\subsection{Transformasi QGIS to Web}

Dengan bantuan Plugin dari QGIS yang bernama QGIS2 Web transformasi dari bentuk format QGIS dijadikan bentuk file html. Dalam Penelitian ini Peneliti menggunakan Sistem Operasi Ubuntu 18.04 dan Web Server Apache 2 ditambah PHP 7 serta database Mysql.

\subsection{Perancangan Database}


Format template yang telah didapatkan oleh Peneliti dari Badan Nasional Penanggulangan Bencana (BNPB) dalam format excel. Dari Format tersebut dijadikan lagi dalam bentuk normalisasi database oleh Peneliti. Tujuan dari normalisasi database adalah agar dapat menampung query Big data dengan konsep data warehouse.

\subsection{Framework Laravel}

Dalam implementasi menjadi bentuk Web Based Peneliti menggunakan suatu kerangka website yang paling populer. Peneliti menjatuhkan pilihan kepada framework PHP yang bernama Laravel dimana di dalamnya sudah terdapat beberapa yang diperlukan dalam implementasi QGIS dan Laravel.

\section{HASIL DAN PEMBAHASAN}

Penelitian ini menggunakan data Covid-19 Kabupaten Ketapang. Untuk menjaga kerahasiaan pasien Covid-19 di Kabupaten ketapang maka nama pasien dan koordinat pasien sudah direkayasa sehingga data dalam tulisan ini bersifat random dari data asli. Data pasien yang berjumlah 144 data ini akan dibuatkan dalam bentuk titik titik koordinat dengan 3 kategori warna. Dengan 3 titik warna hijau berstatus ODP, warna biru berstatus OTG, dan warna pink berstatus PDP. Dalam tulisan ini menggunakan atribut sebanyak 17 atribut yang sangat detail. Adapun atribut yang digunakan adalah Create At dengan tujuan melihat tanggal awal di inputnya pasien, Update At dengan tujuan mengetahui perubahan status dari pasien, nama, alamat, koordinat latitude dan longitude, status pasien, umur, jenis kelamin, Kabupaten, Kecamatan, Kelurahan, transportasi, negara kunjungan, daerah kunjungan, dan lokasi rawat.

\subsection{Implementasi QGIS}

Penelitian ini menggunakan QGIS yang paling terbaru dengan Versi 3.12.2 Bucuresti dibantu database dari PostgreSql Client Version 10.12 (Ubuntu 10.12-0 dan Ubuntu0.18.04.1). Sistem operasi yang digunakan dalam tulisan ini adalah Ubuntu version 18.04.1 LTS.

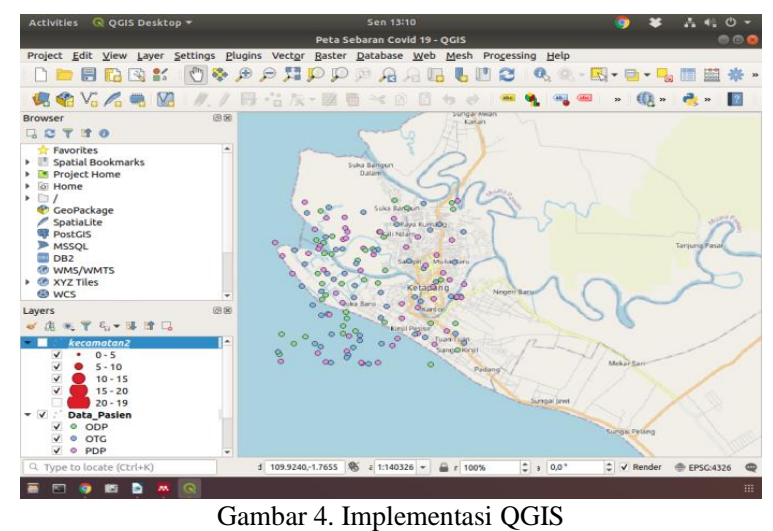

Pada Gambar 4 menunjukan aplikasi QGIS yang masih utuh dalam pembuatan peta. Dalam hal ini sudah didapatkan titik-titik koordinat yang berdasarkan data covid. Penentuan titik pada Gambar 4 merupakan hasil data olahan sehingga bukan menunjukan data asli pasien Covid-19. Data - Data yang telah diolah harus dijadikan dalam bentuk CSV (Comma Save Value) agar dapat di impor ke dalam QGIS. Dengan bantuan plugin Quick Map Service dapat digunakan 3 map sekaligus. Peneliti menggabungkan beberapa map sekaligus yaitu Open Maps Street, Google Maps dan Google Satelit Hybrid.

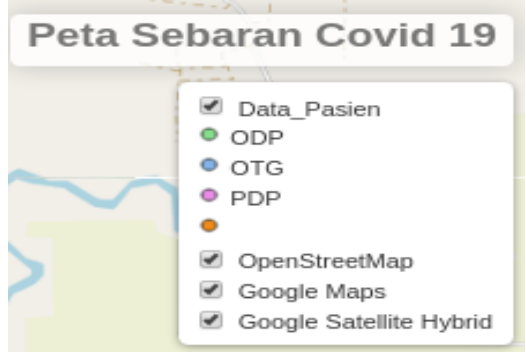

Gambar 5. Kategori Status Pasien

Pada Gambar 5 merupakan status pasien covid dijadikan 3 kategori yang dapat dilihat sebaran titik pasien berdasarkan warna.

4.2 Transformasi QGIS ke Web

Setelah dibuat titik pasien yang berdasarkan warna dengan status pasien pada aplikasi QGIS. Penelit menggunakan plugin QGIS yang bernama QGIS2Web. Pada penelitian, ini data yang ditampilkan dalam mode inline label adalah nama, alamat, Status dan umur. Sedangkan data no label adalah X dan Y. Khusus data pasien dibuat menjadi visible agar dapat dilihat oleh pengguna. Adapun Appearance yang digunakan seperti Add Layers List dengan tujuan dapat melihat status pasien berdasarkan filter warna, Enable Geolocation User agar user dapat mengetahui posisi pasien covid berdasarkan posisi user sekarang, Highlight on Over agar pada aplikasi website nantinya ketika kursor di atas titik koordinat secara otomatis menampilkan pasien. Hasil export dari QGIS2Web dengan format $\mathrm{html}$ sehingga Penulis perlu konversasi kembali dari bentuk Html ke PPH agar mudah dibaca oleh framework Laravel.

\subsection{Rancangan Database}

Penelitian ini merupakan pembuatan server dari aplikasi QGIS yang dapat memetakan pasien Covid-19. Sistem operasi yang digunakan oleh Penulis adalah Ubuntu 18.04 dengan Web Server Apache2, PHP 7 dan Mysql sebagai database. Pada Gambar 6 merupakan rancangan database yang digunakan dalam sistem pemetaan pasien Covid-19. Dengan desain database yang sudah di normalisasi maka dapat menampung data pasien hingga tak terhingga. 


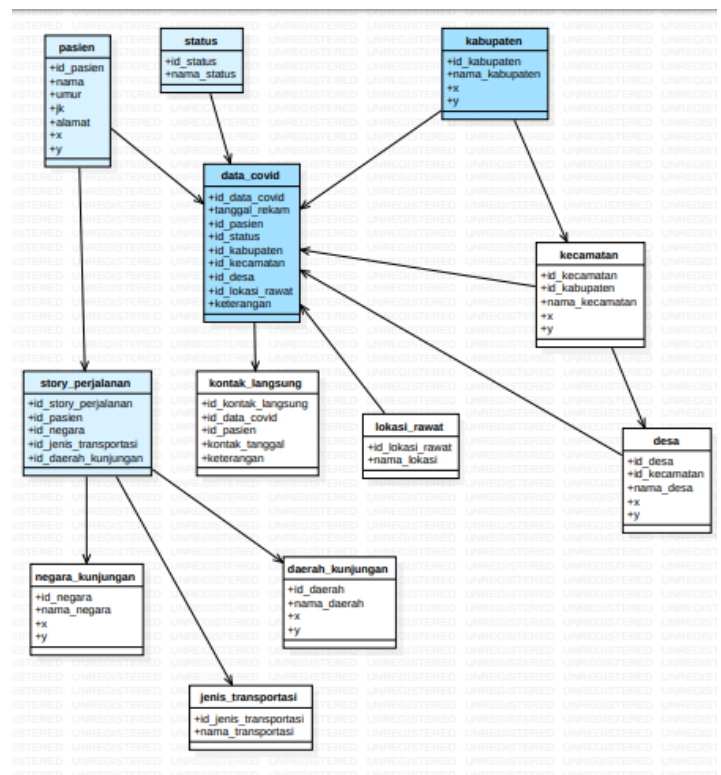

4.4 Implementasi

Gambar 6. Rancangan Database

Tahap terakhir dari penelitian ini adalah implementasi server pemetaan pasien Covid-19 ini kedalam sistem. Peneliti merekomendasi sistem operasi linux ubuntu sebagai server karena dengan sistem operasi linux yang sifatnya open source dan tidak akan ada kendala pembajakan sistem operasi.

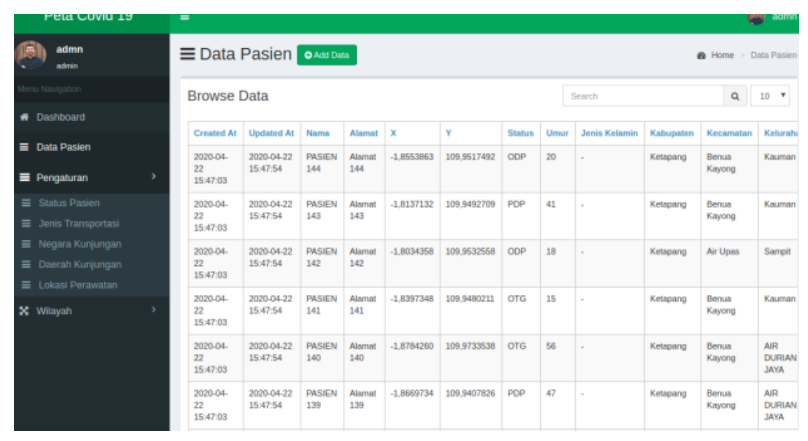

Gambar 7. Halaman Admin

Pada Gambar 7 merupakan halaman admin server dalam mengelola data pasien Covid-19. Ketika data ditambahkan dengan koordinat Latitude dan Longitude maka secara otomatis pada aplikasi website pemetaan pasien Covid-19 menambah titik berdasarkan warna status dari pasien.

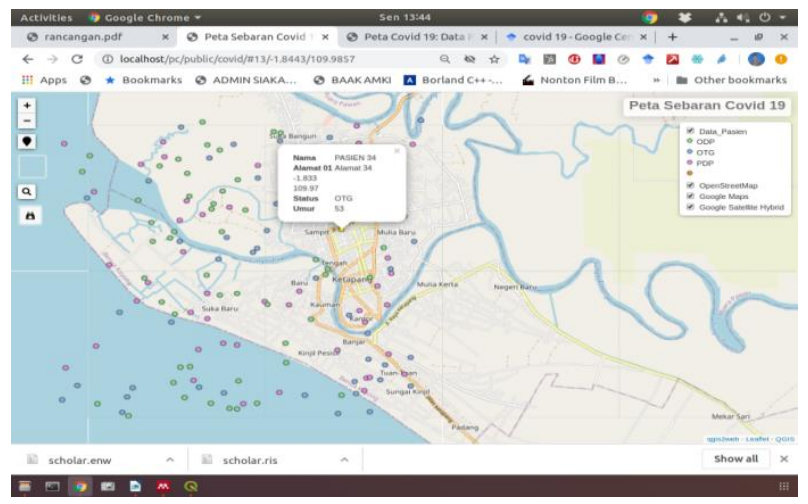

Gambar 8. Peta Sebaran Pasien Covid-19 (Web Version)

Pada Gambar 8 merupakan versi web yang telah selesai dibuat. Peneliti membuat aplikasi ini menjadi open source sehingga silahkan diubah berdasarkan kebutuhan. Dalam hal ini Peneliti juga telah mengunggah file dari web version pemetaan Covid-19 ini ke Github. Jika ada yang ingin berkontribusi pada penyempurnaan peta Covid-19 ini dapat dilihat pada halaman https://github.com/ullilfahri?tab=repositories.

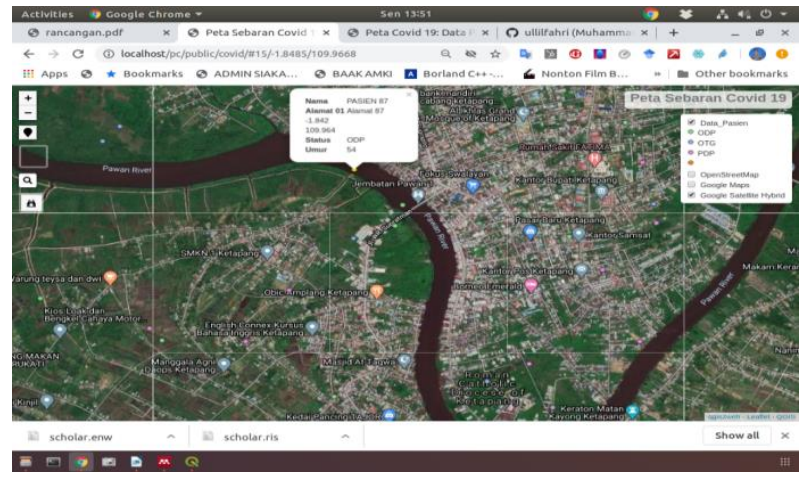

Gambar 9. Google Satelite Hybrid

Pada Gambar 9 merupakan wujud pemetaan pasien Covid-19 yang juga mendukung versi dari Google satelit Hybrid. Pemetaan ini dapat mempermudah melihat rumah pasien berdasarkan tempat tinggal.

\section{KESIMPULAN}

Tulisan ini telah membuat sebuah implementasi aplikasi pemetaan pasien Covid-19. Diharapkan aplikasi hanya digunakan oleh pihak yang memiliki kepentingan seperti rumah sakit yang berwenang. Dengan tujuan dapat membantu rumah sakit melihat sebaran peta pasien yang nyata dan dapat membantu pemerintah melacak suatu daerah yang termasuk zona merah. Diharapkan pada penelitian selanjutnya dapat membantu menyempurnakan aplikasi pemetaan Covid-19 ini dengan berkolaborasi melalui Github. Dan juga sangat diharapkan pada data pasien Covid-19 secara otomatis 
membuat cluster pasien berdasarkan data dengan metode data mining.

\section{Ucapan Terima Kasih}

Terima kasih kepada pihak BNPB Ketapang, Kalimantan Barat yang telah bersedia memberikan format Data Pasien Covid-19 pada penelitian ini. Format yang telah diberikan oleh pihak BNPB Ketapang merupakan sebagai acuan dalam pembuatan Database. Terima Kasih kepada pengelola Jurnal Teknologi Terpadu (JTT) yang dikelola oleh Sekolah Tinggi Teknologi Terpadu Nurul Fikri yang telah bersedia menerbitkan penelitian saya ini. Selain itu, peneliti juga berterima kasih kepada reviewer yang telah meluangkan waktu agar penelitian ini menjadi lebih baik.

\section{DAFTAR PUSTAKA}

[1] N.p., "Novel Coronavirus (COVID-19) Cases Data," 2020. [Online]. Available: https://data.humdata.org/dataset/novel-coronavirus-2019ncov-cases. [Accessed: 18-Apr-2020].

[2] Gugus Tugas Percepatan Penanganan Covid-19, "Peta Sebaran Kasus Per Provinsi," 2020. [Online]. Available: https://covid19.go.id/peta-sebaran. [Accessed: 18-Apr-2020].

[3] E. Dong, H. Du, and L. Gardner, "An interactive webbased dashboard to track COVID-19 in real time," Lancet Infect. Dis., vol. 20, no. 5, pp. 533-534, 2020.

[4] H. S. Letsoin, A. J. Santoso, and Suyoto, "Designing Web-based GIS Application by CSF Method: A Case Study in Boven Digoel Papua," E3S Web Conf., vol. 31, no. January, 2018.

[5] A. Ardiansyah and K. Kardono, "Sistem Informasi Geografis (Sig) Pemetaan Jaringan Pipa Dan Titik Properti Pelanggan Di Pt Aetra Air Tangerang," J. Ilm. FIFO, vol. 9, no. 1 , p. 81, 2017.

[6] Andri Permana Wicaksono, A. Fariza, and Arif Basofi, "Sistem informasi geografis pemetaan jalur kereta api dan analisa traffic," pp. 1-6.

[7] D. Telaumbanua, "Urgensi Pembentukan Aturan
Terkait Pencegahan Covid-19 di Indonesia," QALAMUNA J. Pendidikan, Sos. dan Agama, vol. 12, no. 01, pp. 59-70, 2020.

[8] D. Anggraeni, "Urgensi Pelaksanaan Persidangan Secara Elektronik Guna Penanggulangan Wabah Pandemic Covid-19," $2020 . \quad$ [Online]. Available: http://lppm.unpam.ac.id/2020/04/07/urgensi-pelaksanaanpersidangan-secara-elektronik-guna-penanggulangan-wabahpandemic-covid-19/. [Accessed: 18-Apr-2020].

[9] N. R. Yunus, "Kebijakan Covid-19 , Bebaskan Narapidana dan," ADALAH Bul. Huk. Keadilan, vol. 4, pp. 16, 2020.

[10] A. Ariyanto, D. E. Kurniawan, and A. Fatulloh, "Rancang Bangun Aplikasi WebGIS untuk Pemetaan Kondisi Sosial Ekonomi Kota Batam," J. Appl. Informatics Comput., vol. 2, no. 1, pp. 27-30, 2019.

[11] M. Jasri and R. Setyobudi, "Mapping Student Scholarship Recipients With QGIS Cloud di Kabupaten Probolinggo," vol. 3, no. 2, pp. 10-14, 2018.

[12] M. I. Susanto, E. Darwiyanto, and G. A. A. Wisudawan, "Pengukuran Software Metric Terhadap Implementasi Framework Laravel Pada Pembangunan Aplikasi Berbasis Web," J. Log., vol. 2, no. 3, pp. 7731-7738, 2015.

[13] M. A. S. O. D. W. Firma Sahrul B, "Implementasi Sistem Informasi Akademik Berbasis Web Menggunakan Framework Laravel," J. Transform., vol. 12, no. 1, pp. 1-4, 2017. 